\title{
All Hands on Deck: The Federal Health Care Response to the COVID-19 National Emergency
}

\author{
Life's most persistent and urgent question is: What are you doing for others?
} Martin Luther King Jr.

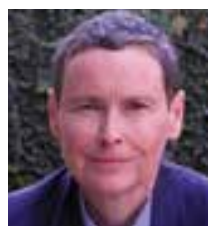

Cynthia M.A. Geppert, MD, Editor-in-Chief Correspondence: Cynthia Geppert (ethicdoc@ comcast.net)

Fed Pract. 2020;37(8):346-347. doi: $10.12788 /$ fp. 0036
A torrent of blame has deluged the administration's management of the pandemic. There is though one part of the government that deserves the praise of the nation for its response to this public health crisis-the federal health care system. In this column, we discuss the ways in which the Veterans Health Administration (VHA), the Department of Defense (DoD), and the US Public Health Service (PHS) Commissioned Corps especially have bravely and generously responded to the medical emergency of COVID-19 in the US.

Four missions drive the US Department of Veterans Affairs (VA). Though the fourth of these missions usually is in the background, it has risen to the forefront during the pandemic. To put the fourth mission in its proper perspective, we first should review the other 3 charges given to the largest integrated health care system in the country.

The first mission is to provide the highest quality care possible for the more than 9 million veterans enrolled in that system at each of the 1,255 VHA locations. The second mission is to ensure that the Veterans Benefits Administration delivers the full range of benefits that veterans earned through their service. These including funding for education, loans for homes, and many other types of support that assist service men and women to be successful in their transition from military to civilian life. The third mission is to honor the commitment of those who fought for their country unto death. The National Cemeteries Administration oversees 142 national cemeteries where veterans are buried with dignity and remembered with gratitude for their uniformed service. The purpose of these 3 internally focused missions is to provide a safety net for eligible veterans from the day they separate from the military until the hour they pass from this earth.
The fourth mission is different. This mission looks outside the military family to the civilian world. Its goal is to bolster the ability of the nation as a whole to handle wars, terrorism, national emergencies, and natural disasters. It does this through emergency response plans that preserve the integrity of the 3 other missions to veterans while enhancing the capacity of local and state governments to manage the threat of these public health, safety, or security crises. ${ }^{1}$

At the same time the VA was aggressively mounting a defense against the threat COVID-19 posed to the other missions, it also launched the fourth mission. In announcing these actions in April 2020, VA Secretary Robert Wilke succinctly summarized the need to balance the fourth mission with the other 3 . "VA is committed to helping the nation in this effort to combat COVID-19. Helping veterans is our first mission, but in many locations across the country we're helping states and local communities. VA is in this fight not only for the millions of veterans we serve each day; we're in the fight for the people of the United States."

During the $2009 \mathrm{H} 1 \mathrm{~N} 1$ pandemic I saw firsthand how VA disaster preparedness and emergency training were far superior to many academic and community health care systems. Given VA's detailed and drilled crisis response plans, its specialized expertise in public health disasters, and its immense resources, it is no wonder that as the virus stretched civilian health care systems, some states turned to the VA for help. At my Albuquerque, New Mexico, VA medical center, 5 medical surgical beds and 3 intensive care beds were opened to the Indian Health Service overwhelmed with cases of COVID-19 in the hard-hit Navajo Nation. In New Jersey where Federal Practitioner is published, the fourth mission reached out to the 
state-run veterans homes as 90 VA nurses and gerontologists were deployed to 2 of its veterans facilities where close to 150 veterans have died. ${ }^{3}$ State veterans homes in Massachusetts, Pennsylvania, Alabama, and many other states have received supplies, including direly needed testing and personal protective equipment, staff, technology, and training. ${ }^{4}$

In July, VA published an impressive summary of fourth mission activities, which I encourage you to read. When you are look at this site, remember with a moment of silent appreciation all the altruistic and courageous VA clinical and administrative staff who volunteered for these assignments many of which put them directly in harm's way. ${ }^{5}$

The VA is not alone in answering the call of COVID-19. In March, despite the grave risk to their health, their life, and their families, the USNS Comfort was deployed to New York City to help with its COVID-19 response while the USNS Mercy assisted in the efforts in Los Angeles. More recently, the military deployed $>700$ Military Health System medical and support professionals to support COVID-19 operations in both Texas and California. Brooke Army Medical Center in San Antonio has taken on a handful of civilian patients with COVID19 and increase its level I trauma cases as local hospitals have strained under the caseload. ${ }^{6}$

For the PHS Commissioned Corps its first mission is to serve as "America's health responders." This pandemic has intensified the extant health inequities in our country and compounded them with racial injustice and economic disparity. Thus, it is important to recognize that the very purpose of the PHS is to "fight disease, conduct research, and care for patients in underserved communities across the nation." ${ }^{8}$ More than 3,900 PHS officers have been deployed nationally and internationally in COVID-19 clinical strike teams. Early in the pandemic the clinical response teams were deployed to a long-term care facility in Kirkland, Washington; convention center-based hospitals in New York City, Detroit, Michigan, and Washington DC, and Navajo Nation facilities. PHS officers also are providing clinical guidance at Bureau of Prison facilities for infection control and personal protective equipment training.
We know that there are many more examples of heroic service by federal health care professionals and staff than we could locate or celebrate in this brief column. Readers of this journal are well aware of the near constant criticism of the VA and calls for privatization, ${ }^{9}$ the inadequate funding of the PHS, ${ }^{10}$ and the recent downsizing of DoD health care ${ }^{11}$ that threatens to undermine its core functions. The pandemic has powerfully demonstrated that degrading the ability of federal health care to agilely and masterfully mobilize in the event of a public health disaster endangers not just veterans and the military but the health and well-being of a nation, particularly its most vulnerable citizens.

\section{Disclaimer}

The opinions expressed herein are those of the author and do not necessarily reflect those of Federal Practitioner, Frontline Medical Communications Inc., the US Government, or any of its agencies.

\section{References}

1. US Department of Veterans Affairs. About VA: VA mission statement. https://www.va.gov/about_va. Updated April 8, 2020. Accessed August 3, 2020.

2. US Department of Veterans Affairs, Office of Public and Intergovernmental Affairs. VA announces 'Fourth Mission' actions to help America respond to COVID-19. https://www.va.gov /opa/pressrel/pressrelease.cfm?id=5420. Published April 14, 2020. Accessed August 3, 2020.

3. Dyer J. COVID-19 strikes hard at state-run veterans nursing homes. https://www.mdedge.com/fedprac/article/221098 /coronavirus-updates/covid-19-strikes-hard-state-run -veterans-nursing-homes. Published April 21, 2020. Accessed August 3, 2020

4. Leigh D. Coronavirus news: VA secretary addresses COVID19 deaths among veterans in the tri-state. https://abc7ny .com/va-secretary-veteran-covid-19-deaths-nursing-homes -veterans-memorial-home/6227770. Published June 3, 2020. Accessed August 3, 2020.

5. US Department of Veterans Affairs, Veterans Health Administration. VA Fourth Mission Summary. https://www.va.gov /health/coronavirus/statesupport.asp. Updated August 3, 2020. Accessed August 3, 2020.

6. Sanchez E. BAMC adapts to support greater San Antonio community during COVID-19 pandemic. https://www.health .mil/News/Articles/2020/07/15/BAMC-adapts-to-support -greater-San-Antonio-community-during-COVID-19 -pandemic. Published July 17, 2020. Accessed August 3, 2020.

7. US Public Health Service. Commissioned Corps of the U.S. Public Health Service: America's health responders. https:// www.usphs.gov/default.aspx. Accessed August 3, 2020.

8. Kim EJ, Marrast L, Conigliaro J. COVID-19: magnifying the effect of health disparities. J Gen Intern Med. 2020;35(8):24412442. doi:10.1007/s11606-020-05881-4

9. Gordon S, Craven J. The best health system to react to COVID-19. The American Prospect. March 20, 2020. https:// prospect.org/coronavirus/the-best-health-system-to-react-to -covid-19. Accessed August 1, 2020.

10. Lessons from the COVID-19 pandemic: it's time to invest in public health. Fed Pract. 2020;37(suppl 3):S8-S11.

11. Wright O, Zuegel K. COVID-19 shows why military health care shouldn't be downsized. https://www.militarytimes.com /opinion/commentary/2020/03/31/covid-19-shows-why -military-health-care-shouldnt-be-downsized. Published March 31, 2020. Accessed August 1,2020. 